\title{
The impact of war on forest areas in the Democratic Republic of Congo
}

\author{
Dirk Draulans and Ellen Van Krunkelsven
}

\begin{abstract}
This paper provides a review of data on the effects of the civil war on forest areas in the Democratic Republic of Congo. Only a few of these effects were beneficial, the most important being the collapse of the wood industry. However, the war has increased the number of people that rely on wood for fuel and bushmeat for protein. The presence of soldiers and refugees aggravates this pressure. When people hide they do not necessarily refrain from hunting, because goods, including ivory, can be stocked to be traded when the situation
\end{abstract}

improves. War seems beneficial to the environment only if it keeps people out of large areas. It could be useful to extend the concept of peace parks to war zones. The idea of an international 'green force' to protect biodiversity hotspots should be given serious consideration. Awareness is growing that political instability should not preclude conservation efforts from being continued.

Keywords Africa, biodiversity, bushmeat, Democratic Republic Congo, forests, hunting, war.

\section{Introduction}

Nearly twenty African countries have experienced civil war since 1960 (Bolle, 2000). In the Democratic Republic of Congo (DRC) 1.7 million people are thought to have died as a direct or indirect consequence of the ongoing war (Roberts, 2000). The impact of this war on the environment is poorly documented, despite the Congo River Basin being one of the three remaining major tropical wilderness areas in the world (Mittermeier et al., 1998).

The DRC, affected by instability since the beginning of the 1990s and by all out war since 1996, contains more than half of Africa's remaining forests (Wolfire et al., 1998; Van Dorp \& Hewitt, 2000). It is the only country in the world that has three species of great apes, including the endemic bonobo Pan paniscus (Van Krunkelsven et al., 2000). Great apes are particularly vulnerable in wartime: Wrangham (quoted in Saegusa, 2000) stated that worldwide more than two-thirds of the 23 protected areas with great apes have been disturbed by military conflicts during the past 10 years.

There are almost no data on the impact of war on biodiversity. The general effects of conventional war on the environment have been described for Indochina (Westing, 1976), the (then) USSR (Smirnov, 1989) and Afghanistan (Formoli, 1995). Reviews of the impacts of African civil wars were based mainly on short anec-

Dirk Draulans and Ellen Van Krunkelsven Société Salonga Museumlaan, 61 B-3080, Tervuren, Belgium. E-mail: ddraulans@knack.be

Received 28 December 2000. Revision requested 29 May 2001.

Accepted 4 September 2001. dotal communications (Westing, 1992) or press reports (Terborgh, 1999). Only for the Rwandan civil war are more details available (Biswas \& Tortajada-Quiroz, 1996; Plumptre et al., 1997; Bouché, 1998; Kanyamibwa, 1998; Werikhe et al., 1998).

Ongoing civil wars in Africa force scientists into serious reflections on the impact of conflicts on conservation (Oglethorpe \& Ham, 1999; Blom et al., 2000; Milius, 2000). Here we present a review of available information, partly from personal experience, on warrelated environmental pressures in the DRC. We spent a total of almost two years in different parts of the DRC during the war (Table 1). The information presented was collected during these visits, unless otherwise indicated.

Table 1 Number of days spent by the authors in the Democratic Republic of Congo and Rwanda*.

\begin{tabular}{llcl}
\hline Year & Author & Number of Days & Area Visited \\
\hline 1991 & DDR & 41 & Rwanda-East DRC \\
1994 & DDR & 40 & Rwanda-East DRC \\
1994 & EVK & c. 90 & Equateur Province \\
1995 & DDR & 22 & East DRC \\
$1995-96$ & EVK & c. 250 & Equateur Province \\
1996 & DDR & $38^{2}$ & Equateur Province \\
1996 & DDR & 29 & East DRC \\
1997 & EVK & 27 & Equateur Province \\
1997 & EVK-DDR & 16 & East DRC and Equateur \\
\multicolumn{5}{c}{ 1997-98 } & EVK-DDR & 42 & Province \\
1999 & DDR & 24 & Equateur Province \\
2001 & DDR & 35 & Equateur Province \\
& & & Rwanda-East DRC \\
*time spent in Kinshasa or other sites of preparation not included \\
20verlap with EVK trip
\end{tabular}




\section{The evidence}

\section{Soldiers}

The number of weapons and ammunition circulating in the DRC has increased substantially during the last ten years. Up until about 1995 the possession of modern arms was usually limited to army personnel in towns and groups of poachers elsewhere. The latter were often soldiers, sent in, and sometimes legally protected, by high ranking officers. They operated as criminal gangs, terrorising villages and traders (Van Krunkelsven et al., 2000; Draulans, 2001a).

This kind of terrorisation seems to have increased. During most of 2000 a frontline cut through the heart of the DRC (Fig. 1), destabilising farming and fishing populations. Elsewhere, mainly in the east, marauding gangs of renegade soldiers, local tribesmen, armed refugees or criminals controlled large areas. Most soldiers are not paid and rely on villagers to support them. Sometimes they provided hunters with bullets, keeping relatives as hostages to make sure that food was delivered. Soldiers occassionally had to move along a frontline (in the Equateur province) as they finished all the food (including fruit and bushmeat) in their original position.

Some rebel leaders are aware of the possibilities provided by conservation to promote their goals internationally. The Front for the Liberation of Congo (FLC), which is supported by Uganda and controls the north and north-east of the DRC, included in its manifesto, that it "favours a sustainable exploitation of natural resources and a politics of systematic reforestation of destroyed places". It also envisages "strengthening cooperation in the sector of protection of national parks and threatened

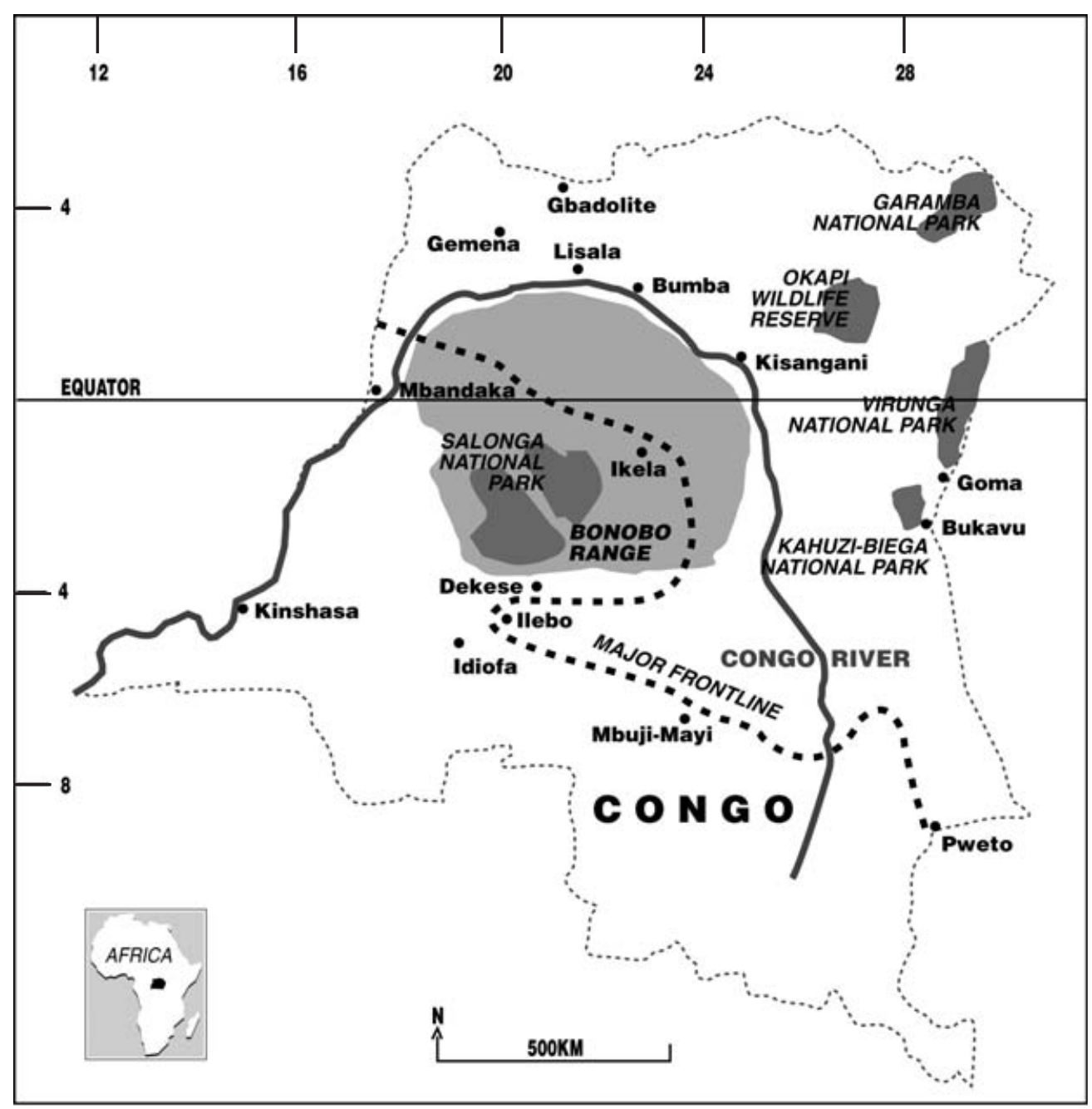

Fig. 1 The political situation in the Democratic Republic of Congo during most of 2000. The dotted line is the main frontline, which cuts through the bonobo range (lightly shaded area). The five World Heritage Sites (dark shaded areas), the Congo River and some key towns are shown. 
species" (Mouvement de Libération du Congo, 1999). The FLC sees value in forest exploitation, but did take steps to remove coltan diggers from the Okapi Wildlife Reserve (Draulans, 2001b). It stated that elephants Loxodonta africana need to be protected, although a lot of ivory is being traded in its area, both by local poachers and Ugandan army officers (Draulans, 1999; United Nations, 2001).

The UN also provided evidence that high ranking Ugandan and Rwandan officers transported valuable logs, which they had had their soldiers cut, to their home countries (United Nations, 2001). In Congo illegal export of logs was used to fuel war efforts (Van Dorp $\&$ Hewitt, 2000). There is evidence from local sources that the Zimbabwean troops that fought alongside DRC's government flew out ivory and grey parrots Psittacus erythacus from towns such as Monkoto in the Equateur province (Draulans, 2001b).

A lot of soldiers were seen with live monkeys or parrots. In Bukavu on the border with Rwanda conservation experts witnessed army personal bringing in chimpansees Pan troglodytes from the interior. Two baby Grauer's gorillas Gorilla gorilla graueri were seen on sale in Bumba (P. Salopek, pers. comm.), at least $500 \mathrm{~km}$ from their original habitat. In Kahuzi Biega National Park (NP) gorilla and elephant populations have been decimated in recent years (Shalukoma, 2000; Vogel, 2000). In spring 2000 there was a substantial increase in the number of bonobo orphans confiscated from soldiers in DRC's capital Kinshasa (Minesi, in Vogel, 2000).

\section{Refugees}

The impact of, the mainly Rwandan, refugees on the environment in the DRC has been devastating, especially in the east. If they were accompanied by armed men, roaming refugees would force villagers to feed them or would raid their fields. If they were unarmed, local people would try to help them. In all circumstances refugees substantially increased the pressure of the human population on the available resources. In some instances this increase resulted in the local population itself being forced to start moving, mainly towards small towns, or to increase its reliance on fish and wildlife when available.

The impact of refugee camps on the environment has been documented (Biswas \& Tortajada-Quiroz, 1996; Draulans, 1997; Werikhe et al., 1998; Sato et al., 2000). The end of the Rwandan civil war in 1994 caused 1.5-2 million people to flee, largely towards the DRC (then Zaire). More than $150 \mathrm{~km}^{2}$ of forest from the Virunga NP was cut by refugees. Many camps housed armed and frustrated people, which made protection of the parks almost impossible. The amount of poaching increased substantially: the number of snares and machetes confiscated in Virunga NP tripled in 1994 and 95. Park guards and gorillas were killed in both Virunga and Kahuzi-Biega NP.

\section{The local human population}

People learn to adapt to the disturbance caused by refugees or soldiers. In the first instance they will work on their fields at night to avoid being harassed. When this is impossible, or when the pressure from refugees or soldiers is too high, they flee into the forest, where they try to make a living from fishing and hunting (mainly using snares and traps, but sometimes using traditional methods such as bows and poisoned arrows). Some people prefer remote or protected areas, both for security reasons and because of the abundance of wildlife that can be hunted, unless these areas are infested by professional poachers.

Even before the war many people in the DRC were dependent on natural resources for their survival. The collapse of the transport system increased the reliance on bushmeat to about $80 \%$ of protein consumed (Wilkie et al., 1998). Wolfire et al. (1998) estimated that $80 \%$ of energy consumption in the DRC came from fuel wood. During the war transport along rivers, including the Congo, the Lulonga and the Tshuapa, was almost impossible. Bushmeat was available on many village markets, but it was hard to evaluate to what degree the impossibility of trading with large towns, such as Mbandaka and Kinshasa, affected the intensity of hunting.

The amount of trade seemed to be inversely proportional to the number of road or river blocks encountered, where goods may be confiscated or stolen. Road or river blocks tend to be installed by official forces, such as those of the government, or forces that are losing ground. In such areas it may appear that trade and hunting have largely been abandoned, substantiating claims that conflicts could be beneficial for wildlife.

However, some people keep hunting but hide their catch until the situation improves. Only one week after rebel forces took the towns of Gemena and Gbadolite in North-Congo from government troops, hunters arrived with large amounts of bushmeat and small stocks of ivory that they had hidden in the forest (Draulans, 1999). Such situations also attract traders, often Lebanese, who come 'prospecting' for anything ranging from diamonds to wildlife. One trader visited villages to place orders for skins of the leopard Panthera pardus.

The forest industry suffered heavily from the war. During visits in 1999 and 2000 there was hardly any activity in once flourishing ports, such as Lisala and Bumba on the Congo River. Kisangani was almost totally cut off from commercial river transport. These three 
towns were crucial to foresters, and the official export of logs from the DRC dropped dramatically in recent years (Fig. 2). Van Dorp \& Hewitt (2000) stressed that wood production fell to zero in the Equateur Province as a consequence of the war.

In contrast, the quantity of logs being transported from East-DRC to Uganda doubled, although the official amounts were much lower than those exported from the DRC before the war (United Nations, 2001). Local loggers claim that the war forced them to abandon all efforts to log sustainably (Draulans, 2001b). In spring 2001 a Mayi-Mayi brigade took 25 foreign hostages from the Ugandan-Thai Dara Forest Company, claiming that the company was destroying the area where they live.

\section{Discussion}

War can have beneficial effects on the environment. Martin \& Szuter (1999) described how in the 19th century American bison Bison bison survived in large numbers on the borders between Indian nations that were at war. More recently biodiversity seems to be thriving in Korea's demilitarized zone (Kim, 1997). Smirnov (1989) described how, during the world wars, packs of wolves Canis lupus followed troops in the former USSR to feed on dead bodies - the species' populations increased with every war. There is evidence that in south Sudan hyenas Hyaena hyaena are attacking refugees, who are forced to sleep outside at night (Draulans, 1997). During the Zimbabwean civil war the population of elephants in the Hangwe National Park increased beyond local

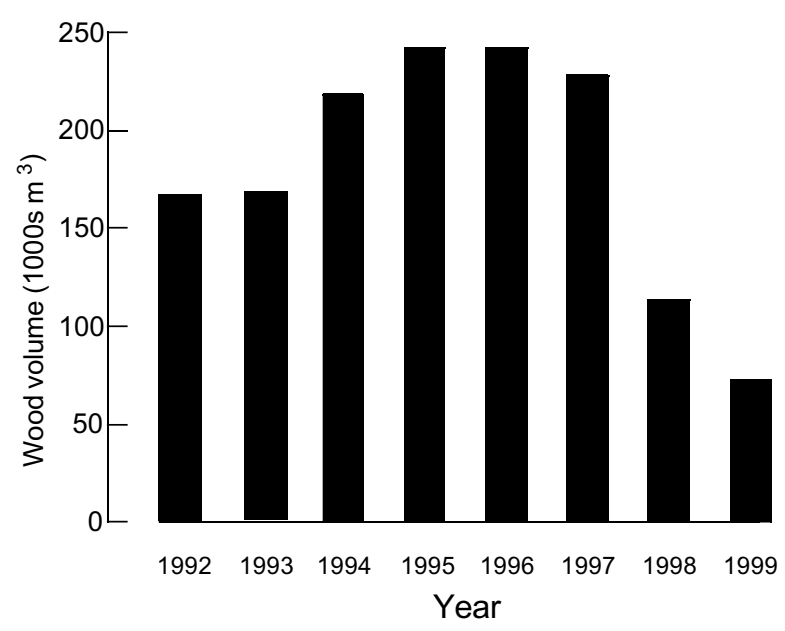

Fig. 2 Changes in the volume of timber exported from the Democratic Republic of Congo during 1992-1999 (from Van Dorp \& Hewitt, 2000, with additional data from J. Hewitt). carrying-capacity because the situation had become too dangerous for poachers (Hallagan, 1981). Plumptre et al. (1997) noticed that forest buffalo Syncerus caffer did well in part of the Rwandan Volcano NP during the war because the presence of the army made the area too dangerous for poachers. Similarly large numbers of lions Panthera leo and topis Damaliscus korrigum roamed Rwanda's Akagera NP in spring 1991, a year after the start of the civil war (Draulans, 1997).

In contrast, Kanyamibwa (1998) reported that in 1993 the situation in Akagera NP was less positive because poaching had increased substantially. War often appears to be detrimental for wildlife. Elk Alces alces were exterminated in large areas of the former USSR during the First World War (Smirnov, 1989). During World War II German forces hunted the wisent Bison bonasus almost to extinction in Poland (Westing, 1992). The war of 1960-66 in (the then Belgian) Congo decimated the white rhinoceros Ceratotherium simum population in Garamba NP (Curry-Lindahl, 1971-72). Uganda's wildlife suffered heavily from ten years of instability in the 1980s (Van Orsdol, 1980; Forse, 1987). Large mammals were wiped out in many areas of war-torn Mozambique (Oglethorpe in Oglethorpe \& Ham, 1999). The conflicts in Chad and Sudan allowed poachers to eliminate all rhinos and most elephants in the northern part of the Central African Republic (Mokombo, in Oglethorpe \& Ham, 1999). More than 100,000 elephants and 1,000 rhinos were killed by rebels (and South African soldiers) in south-east Angola (Breytenbach, 2001).

War only appears to be profitable for the environment if it keeps people out of large areas. Usually that is not the case, so war can hardly be considered beneficial to biodiversity. Candotti (2000) described the problems faced by conservation organisations as a result of the Congo war. Authorities, for example, lost control over large parts of Kahuzi-Biega and Virunga NPs, because of the presence of armed gangs digging coltan and herding cattle (Draulans, 2001b). Westing (1992) stressed that it is crucial that national parks and World Heritage Sites should be formally demilitarized. The concept of peace parks, initially launched for the creation of transborder parks such as the Virunga volcano chain between Rwanda, Uganda and the DRC (Kalpers \& Lanjouw, 1998), could be extended to parks in war zones, such as Salonga NP in the DRC.

The creation of an international 'green force' for the protection of important areas of biodiversity should be given serious consideration (Sand, 1993; Boulding, 1997; Terborgh, 1999). It is clear from certain reactions to these proposals (quoted in Sand, 1993) that such a force would need strong fighting capabilities.

There seems to be a general reluctance in conservation and other humanitarian organizations to work with 
soldiers and military authorities. This could be misconceived in unstable areas such as the DRC where large quantities of biodiversity may be lost as a consequence of long-lasting war. In Rwanda the army was called in to protect gorillas and researchers in the Volcano NP (Bouché, 1998). Newman (in Oglethorpe \& Ham, 1999) mentioned that the World Wide Fund for Nature (WWF) considered hiring a private military force to protect the northern white rhino in Congo's Garamba NP. Mokombo (in Oglethorpe \& Ham, 1999) described how WWF hired an individual with a military background to train park guards in Central African Republic's Dzanga-Sangha $\mathrm{NP}$, which was invaded by mutineers fleeing fighting. An expedition to Salonga NP, which was invaded by gangs of heavily armed poachers, was successful because soldiers from the government's army were hired for protection (Van Krunkelsven et al., 2000). A large survey team in Kahuzi-Biega NP had to be accompanied by 50 soldiers in order to be able to work (Shalukoma, 2000).

A \$3 million donation from the United Nations Foundation to support five World Heritage sites, all nature areas, in the DRC should provide stimuli for park people to keep working in difficult circumstances. Plumptre et al. (2000) described this initiative as a model for UN involvement in conservation in areas of conflict. It is clear from the extent of the present instability in Central Africa that just waiting until the political situation improves is no longer a viable option for the conservation of biodiversity.

\section{Acknowledgements}

We thank Camilla Erskine for the suggestion to write this paper, and Guy Debonnet, Tom De Meulenaer, Jean-Pierre D'Huart, Marc Herremans, James Hewitt, Tony Mombaers, Johan Peleman, Paul Salopek, Marc Van Dorp and Filip Verbelen for assistance and comments.

\section{References}

Biswas, A. \& Tortajada-Quiroz, C. (1996) Environmental impacts of the Rwandan refugees on Zaire. Ambio, 25, 403-408.

Blom, E., Bergmans, W., Dankelman, I., Verweij, P., Voeten, M. \& Wit, P. (2000) Nature in War. Biodiversity Conservation During Conflicts. The Netherlands Commission for International Nature Protection, Amsterdam.

Bolle, J. (2000) L'Afrique est-elle hors course? Revue des Questions Humanitaires, 11, 56-62.

Bouché, P. (1998) Les aires protégées du Rwanda dans la tourmente. Evolution de la situation de 1990 à 1996. Cahiers d'Ethologie, 18, 161-174.

Boulding, E. (1997) Roles for NGOs in reducing or preventing violence. Transnational Associations, 49, 317-327.
Breytenbach, J. (2001) The Plunderers. Covos Day Books, Johannesburg.

Candotti, S. (2000) The evolving role of an international conservation organisation in times of war: WWF in the Democratic Republic of Congo. In Nature in War (eds E. Blom, W. Bergmans, I. Dankelman, P. Verweij, M. Voeten \& P. Wit), pp. 21-38. Netherlands Commission for International Nature Protection, Amsterdam.

Curry-Lindahl, K. (1971-72) War and the white rhinos. Oryx, 11, 263-267.

Draulans, D. (1997) Een grap van God. Oorlogsreportages uit Afrika. Globe, Groot-Bijgaarden.

Draulans, D. (1999) Zelfs de geiten zijn bevrijd. Knack Magazine, 29 (36), 116-118.

Draulans, D. (2001a) Im Dschungel. Afrika, Affen und andere Leidenschaften. Beck Verlag, Munchen.

Draulans, D. (2001b) Oorlog is kinderspel. Knack Magazine, 31 (18), 126-131.

Formoli, T. (1995) Impacts of the Afghan-Soviet war on Afghanistan's environment. Environmental Conservation, 22, 66-69.

Forse, B. (1987) Uganda mobilises to restore its national parks. New Scientist, 115 (1570), 21.

Hallagan, J. (1981) Elephants and war in Zimbabwe. Oryx, 16, 161-164.

Kalpers, J. \& Lanjouw, A. (1998) Potentialités pour la création d'un Parc pour la Paix dans la région des volcans Virunga. Cahiers d'Ethologie, 18, 187-206.

Kanyamibwa, S. (1998) Impact of war on conservation: Rwandan environment and wildlife in agony. Biodiversity and Conservation, 7, 1399-1406.

Kim, K. (1997) Preserving biodiversity in Korea's demilitarized zone. Science, 278, 242.

Martin, P. \& Szuter, C. (1999) War zones and game sinks in Lewis and Clarks West. Conservation Biology, 13, 36-45.

Milius, S. (2000) When biologists get bombed. Science News, 158, 78-79.

Mittermeier, R., Myers, N., Thomsen, J., Da Fonseca, G. \& Olivieri, S. (1998) Biodiversity hot spots and major tropical wilderness areas: approaches to setting conservation priorities. Conservation Biology, 12, 516-520.

Mouvement de Libération du Congo (1999) Le Mouvement de Libération du Congo, M.L.C.: programme. MLC, Gbadolite.

Oglethorpe, J. \& Ham, R. (1999) Armed conflict and protected areas in Africa. http:/ / www.bsponline.org/africa/3rd level/ disasters/africa2.html

Plumptre, A., Bizumuremyi, J., Uwimana, F. \& Ndaruhebeye, J. (1997) The effects of the Rwandan civil war on poaching of ungulates in the Parc National des Volcans. Oryx, 31, 265-273.

Plumptre, A., Hart, T., Vedder, A. \& Robinson, J. (2000) Support for Congolese conservationists. Science, 288, 617.

Roberts, L. (2000) Mortality in Eastern Democratic Republic of Congo. Results from Five Mortality Studies. International Rescue Committee, Bukavu.

Saegusa, A. (2000) Congo war increases threat to bonobo research. Nature, 405, 262.

Sand, P. (1993) International environmental law after Rio. European Journal of International Law, 4, 377-389.

Sato, H., Yasui, K. \& Byamana, K. (2000) Follow-up survey of environmental impacts of the Rwandan refugees on eastern D.R. Congo. Ambio, 29, 122-123. 
Shalukoma, C. (2000) News from Kahuzi-Biega. Gorilla Journal, $21,3-4$.

Smirnov, N. (1989) The impact of conventional war on natural areas of the USSR. Environmental Conservation, 16, 317-321.

Terborgh, J. (1999) Requiem for Nature. Island Press, Washington D.C.

United Nations (2001) Report of the Panel of Experts on the Illegal Exploitation of Natural Resources and Other Forms of Wealth of the Democratic Republic of Congo. United Nations, New York.

Van Dorp, M. \& Hewitt, J. (2000) Industrial Logging in Ancient Forests. Country Study Democratic Republic of Congo. AIDEnvironment for Greenpeace International, Amsterdam.

Van Krunkelsven, E., Bila-Isia, I. \& Draulans, D. (2000) A survey of bonobos and other large mammals in the Salonga National Park, Democratic Republic of Congo. Oryx, 34, 180-187.

Van Orsdol, K. (1980) 'I witnessed a massacre'. International Wildlife, 10, 28-32.

Vogel, G. (2000) Conflict in Congo threatens bonobos and rare gorillas. Science, 287, 2386-2387.

Werikhe, E., Mushenzi, N. \& Bizimana, J. (1998) L'impact de la guerre sur les aires protégées dans la région des Grands Lacs. Cahiers d'Ethologie, 18, 175-186.

Westing, A. (1976) Ecological Consequences of the Second Indochina War. Almqvist \& Wiksell, Stockholm.

Westing, A. (1992) Protected natural areas and the military. Environmental Conservation, 19, 343-348.

Wilkie, D., Curran, B., Tshombe, R. \& Morelli, G. (1998) Managing bushmeat hunting in Okapi Wildlife Reserve, Democratic Republic of Congo. Oryx, 32, 131-144.
Wolfire, D., Brunner, J. \& Sizer, N. (1998) Forests and the Democratic Republic of Congo. Opportunity in a Time of Crisis. World Resources Institute, Washington D.C.

\section{Biographical sketches}

Dirk Draulans has a $\mathrm{PhD}$ in biological sciences from the University of Leuven, Belgium, and spent two years as a postdoctoral researcher in the Zoology Department of Oxford University, UK. He joined several scientific expeditions to Africa, the last one in 1997/98 to Salonga National Park in the Democratic Republic of Congo. He is now a staff reporter for a Belgian newsweekly with a focus on war and environmental issues. He has covered most of the recent African wars and written several books (in Dutch and German) on his war experiences, some of which hit the top of the bestsellers list in Belgium.

Ellen Van Krunkelsven holds a degree in biology from the University of Antwerp, Belgium, and wrote a dissertation on vocal communication of bonobos in captivity. From 1994 onwards she studied the social interactions of bonobos in the Lomako Forest of Congo/Zaire - work that had to be abandoned because of the turmoil in the country. She organised the first expedition to the heart of Salonga National Park in 1997/98. In anticipation of an improvement of the situation in the DRC she joined a project funded by the Belgian government in which giant pouched rats are trained to detect landmines. 